\title{
Application of Mobile Air Cleaning Devices in daily school routines
}

\author{
Ralph Krause*, Christian Friebe and Ralf Heidenreich \\ Institut für Luft und Kältetechnik gGmbH, 01309 Dresden, Germany
}

\begin{abstract}
The spread of the SARS Cov2 virus in Europe clearly reveals the need of new ventilation concepts. Schools are considered to be one of the main origins of the spread. Therefore, ways to reduce the possibility of indirect infection in everyday school life are investigated. In this paper, the results of field studies are presented. In the course of these studies, different modes of action (filtration, UV-C, photo-catalysis) and room flow concepts (mixed ventilation, displacement ventilation) were considered. The evaluations of the measurements show how the devices influence the sensations of the students (sound pressure level, draught risk, etc.). Furthermore, it shows how the exhaust air capture works and how the room flow is affected. Therefore, ways to reduce the possibility of indirect infection in everyday school life are sought here.
\end{abstract}

\section{Introduction}

While at the beginning of the pandemic spread of the SARS-CoV2 virus it was assumed that spread of the virus happens mainly by smear infections, in the course of 2020 it became evident that the most important transmission path was airborne particles. In the course of this realization, considerations arose as to how the transmission paths can be prevented by different measures. Fig. 1 depicts the classification of different measures to prevent infection by airborne particles. The measures according to this diagram should be selected from top to bottom according to their effectiveness. This article focusses on the engineering measures, which include the use of existing ventilation systems, window ventilation and the use of mobile air cleaning devices

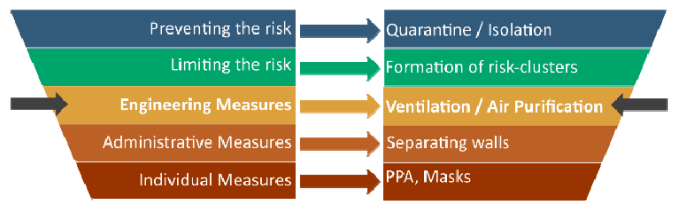

Fig. 1. Classification of different measures to prevent infection by airborne particles.

\footnotetext{
* Corresponding author: ralph.krause@ilkdresden.de
} 
Only in exceptional cases schools are equipped with mechanical ventilation systems. Therefore, in most cases, only window ventilation can be applied. It is evident that, especially in the winter months, window ventilation can only be used to a very limited extent. The reason is the high draught rating, caused by the large difference in temperatures between the indoor and outside air. The use of mobile air cleaning devices is seen as an alternative or supplement to window ventilation. These devices can be installed easily and at moderate costs.

There are many different mobile air purifiers on the market, which operate according to different technical principles. All of them purify the air in the room by means of the recirculation principle. That means the minimum outdoor air exchange rate defined by hygienic requirements must be guaranteed via window ventilation.

ILK Dresden has carried out tests in several schools at different locations to observe the performance of the mobile air purifiers installed in the classrooms. The focus was on considering the influence of the specific conditions on site. In this article, the results are presented and evaluated.

\section{Working principles and test sites}

\subsection{Working principle}

The main task of a mobile air cleaning device is the elimination of airborne pollutants. For this purpose, a part of the room air is permanently extracted with a fan, purified and supplied to the room again. The cleaning process can be performed with different methods. These methods are

- Mechanical filtration (H13/H14, ePM1),

- Electrical filtration (EF),

- Ultraviolet radiation (UVC),

- Photocatalytic treatment (PC),

- Ionisation (IO) and

- Combinations of the aforementioned processes.

The reduction of pathogens is characterised by the method-specific percentage of pollutants emitted back into the room in the discharge compared to the amount of pathogens that entered the unit.

The induced air flow in the room represents a mixed flow regime. Additional supply air is optional. The working principle is represented in Fig. 2.

is optional. The working principle is represented in Fig. 2.

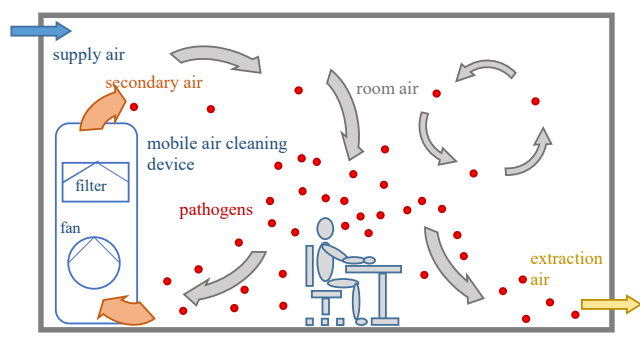

Fig. 2. Mobile air cleaning device and its working principle, the contaminated air enters the cleaning device at its bottom and the pathogens get removed by mechanical filtration, the cleaned secondary air gets reemitted into the room at the top of the device. 


\subsection{Test sites}

Five schools with different classrooms, three high schools and two elementary schools, were selected for the investigation. The classrooms were examined "as they were found". This way the air cleaning devices could operate under authentic conditions and the typical teaching was not influenced.

Normal classes were conducted at the elementary schools. Unfortunately, due to the pandemic situation, no students were present at the high school at the time of the investigation.

Two of the investigated classrooms are exemplified in Fig. 3. The corresponding floor plans are presented in Fig. 4.

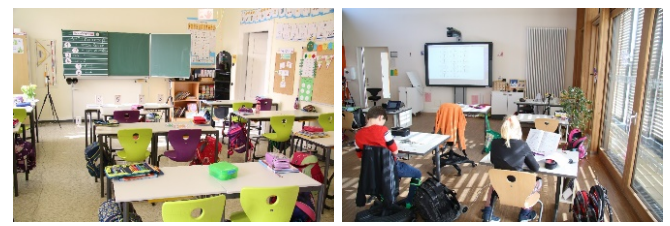

Fig. 3. Classrooms studied as example.

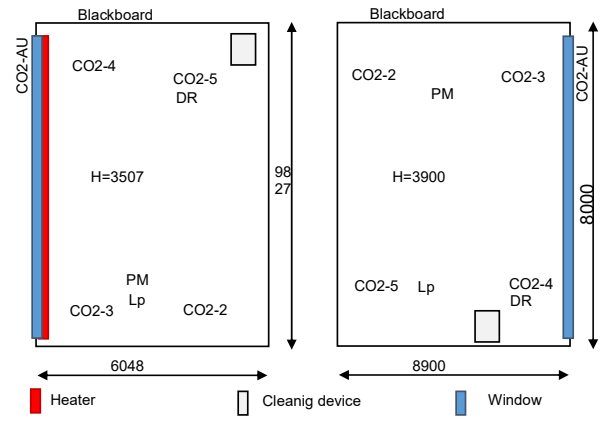

Fig. 4. Floor plans of the classrooms presented in Fig. 3.

The classrooms were equipped with mobile air cleaning devices with different cleaning principles. In addition, a classroom (S\#008) without an air purifier was investigated for reference measurements. An overview of the investigated classrooms and air cleaning principles is presented in Table 1 .

Table 1. Overview of class rooms under test

\begin{tabular}{|c|c|c|c|c|}
\hline No. & school & principle & $\begin{array}{c}\text { No. } \\
\text { persons }\end{array}$ & $\begin{array}{c}\text { Room volume } \\
{\left[\mathbf{m}^{3}\right]}\end{array}$ \\
\hline S\#001 & High school & $\begin{array}{c}\text { ambient air, photo- } \\
\text { catalytic }\end{array}$ & 0 & 200 \\
\hline S\#002 & High School & $\begin{array}{c}\text { ambient air, filtration, } \\
\text { HEPA H14 + ISO } \\
\text { ePM10 } \\
>50 \%\end{array}$ & 0 & 400 \\
\hline S\#003 & High school & extraction air & 0 & 220 \\
\hline S\#004 & Elementary school & ambient air, filtration, & 12 & 278 \\
\hline
\end{tabular}




\begin{tabular}{|c|c|c|c|c|}
\hline & Elementary school & $\begin{array}{c}\text { HEPA H14 } \\
\text { ambient air, filtration, } \\
\text { Prefilter, activated } \\
\text { carbon, cold plasma, } \\
\text { plate collector }\end{array}$ & 12 & 265 \\
\hline $\mathrm{S} \# 0006$ & Elementary school & $\begin{array}{c}\text { ambient air, Prefilter, } \\
\text { HEPA H13, activated } \\
\text { carbon, UVC, } \\
\text { photocatalysis }\end{array}$ & 29 & 196 \\
\hline $\mathrm{S} \# 007$ & Elementary school & $\begin{array}{c}\text { ambient air, filtration, } \\
\text { HEPA H14 }\end{array}$ & 26 & 200 \\
\hline $\mathrm{S} \# 008$ & Elementary school & without air purification & 25 & 196 \\
\hline
\end{tabular}

\section{Data acquisition}

\subsection{Noise level}

The noise level was determined in the middle of the room with a minimum distance of 1 $\mathrm{m}$ to surrounding objects or room surfaces. The sound levels were determined in the octave spectrum within a frequency range from $100 \mathrm{~Hz}$ to $8 \mathrm{kHz}$. Since no tonal components were detected in the spectrum during any of the measurements, only the A-weighted sum levels were used as measurement results.

When students where present the background sound level could only be determined during periods with "silent work" so that the measured sound pressure level clearly can be assigned to the air cleaner. The measured noise levels are compiled in Table 2. Additionally to the noise level during the classes the noise level at the operating point with maximum volume flow of the respective mobile air cleaning device is listed.

Table 2. Noise levels in $\mathrm{dB}(\mathrm{A})$ with mobile air purifier in operation

\begin{tabular}{|c|c|c|c|}
\hline No. & $\begin{array}{c}\text { Background } \\
\text { noise level }\end{array}$ & $\begin{array}{c}\text { Noise level } \\
\text { during } \\
\text { lesson }\end{array}$ & $\begin{array}{c}\text { Noise level at } \\
\text { max. } \\
\text { operating } \\
\text { point }\end{array}$ \\
\hline S\#001 & $\leq 30$ & 43.5 & 43.5 \\
\hline S\#002 & $\leq 30$ & 48.5 & 58.5 \\
\hline S\#003 & $\leq 30$ & 38.7 & 50.0 \\
\hline S\#004 & $\begin{array}{c}\text { silent work } \\
\text { approx. 35 }\end{array}$ & 39.9 & 58.7 \\
\hline S\#005 & $\begin{array}{c}\text { silent work } \\
\text { approx. 35 }\end{array}$ & $-/-$ & 55.7 \\
\hline S\#006 & $\begin{array}{c}\text { silent work } \\
\text { approx. 35 }\end{array}$ & 49.0 & 63.0 \\
\hline S\#007 & $\begin{array}{c}\text { silent work } \\
\text { approx. 35 }\end{array}$ & 50.3 & 76.3 \\
\hline S\#008 & $\begin{array}{c}\text { silent work } \\
\text { approx. 35 }\end{array}$ & $-/-$ & $-/-$ \\
\hline
\end{tabular}

\subsection{Draught rating}

The draught rating was determined in accordance to DIN EN ISO 7730 [1] for each room at selected locations representing a student's learning place near the air cleaning device. 
The draught rating was determined for a seated person at three heights: feet $/ 10 \mathrm{~cm}$, chest $/ 60 \mathrm{~cm}$ and head $/ 110 \mathrm{~cm}$ from the floor. The determined draught ratings at the three heights are compiled in Table 3.

Table 3. Draught rating in percentage unsatisfied

\begin{tabular}{|c|c|c|c|}
\hline No. & Feet & Chest & Head \\
\hline S\#001 & 0.0 & 0.0 & 0.0 \\
\hline S\#002 & 6.6 & 0.0 & 0.0 \\
\hline S\#003 & 12.2 & 9.0 & 6.2 \\
\hline S\#004 & 0.0 & 3.0 & 0.0 \\
\hline S\#005 & 0.0 & 3.5 & 5.0 \\
\hline S\#006 & 0.0 & 0.0 & 4.7 \\
\hline S\#007 & 8.2 & 0.0 & 0.9 \\
\hline S\#008 & $-/-$ & $-/-$ & $-/-$ \\
\hline
\end{tabular}

\subsection{Volume flow rate}

The air flow rate delivered by the units was measured using the net method in accordance with DIN EN 12599 [2]. The results are presented in Table 4. In this table the air flow rates for the adjusted operation point and additionally the air flow rates for maximum volume flow according to the data sheet are listed.

Table 4. Draft risk in percentage unsatisfied

\begin{tabular}{|c|c|c|c|}
\hline No. & $\begin{array}{c}\text { Room } \\
\text { volume } \mathbf{~ m}^{\mathbf{3}}\end{array}$ & $\begin{array}{c}\text { Air flow } \\
\text { rate } \\
\mathbf{m}^{\mathbf{3}} / \mathbf{h}\end{array}$ & $\begin{array}{c}\text { Air flow rate } \\
\text { max. } \\
\text { operation } \\
\mathbf{m}^{\mathbf{3}} \mathbf{h}\end{array}$ \\
\hline $\mathrm{S} \# 001$ & 200 & $2 \times 91$ & $2 \times 130$ \\
\hline $\mathrm{S} \# 002$ & 400 & $2 \times 623$ & $2 \times 1.400$ \\
\hline $\mathrm{S} \# 003$ & 220 & 144 & 406 \\
\hline $\mathrm{S} \# 004$ & 278 & 573 & 1.400 \\
\hline $\mathrm{S} \# 005$ & 265 & 340 & 1.000 \\
\hline $\mathrm{S} \# 006$ & 196 & 375 & 1.000 \\
\hline $\mathrm{S} \# 007$ & 200 & 345 & 1.170 \\
\hline $\mathrm{S} \# 008$ & $-/-$ & $-/-$ & $-/-$ \\
\hline
\end{tabular}

\subsection{Particle concentration and recovery rate}

The decrease in concentration of the particles proofs the ability of the devices to remove aerosols from the room air. In accordance with the correlation with typical Corona-Virus particle sizes, the evaluation focuses on particle sizes from $0.1 \mu \mathrm{m}$ to $0.25 \mu \mathrm{m}$ [3].

The recovery rate can be derived from the decrease-rate of the particle concentrations of naturally seeded particles and describes the amount of room air purified within one hour. The measurement is based on VDI 2083-3 [4] and ISO 14644-3 [5].

Fig. 5 depicts the curve of the particle concentration in $\mathrm{S} \# 006$ in the range from $0.1 \mu \mathrm{m}$ to $0.25 \mu \mathrm{m}$. This is an example of a quiet class, where students mainly worked at their seats. The recovery rates for the nominal operation points are listed in Table 5. Obviously, the particle concentration increases when windows are open. This is due to a high particle concentration in the outdoor air. The reduction of the particle concentration in the room with closed windows can be attributed to the operating principle of the unit. 


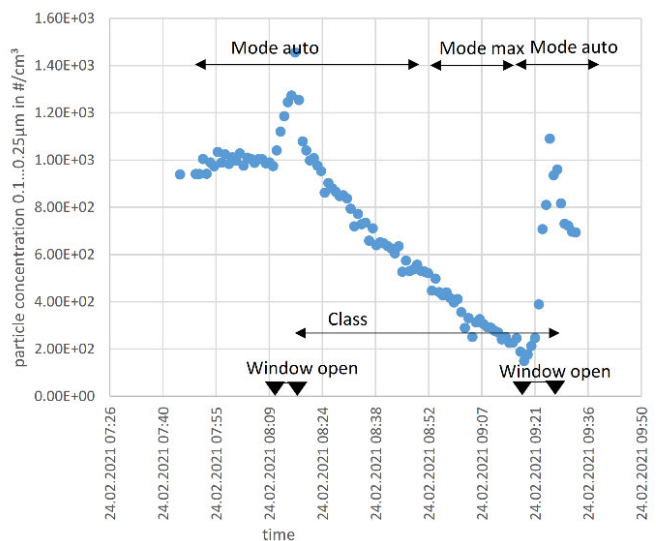

Fig. 5. Concentration of particles at particle size range $0.1 \mu \mathrm{m}$ to $0.25 \mu \mathrm{m}$ during class (S\#006).

Table 5. Recovery rate for nominal operation point

\begin{tabular}{|c|c|c|}
\hline No. & $\begin{array}{c}\text { Room volume } \\
\mathbf{m}^{\mathbf{3}}\end{array}$ & $\begin{array}{c}\text { recovery rate } \\
\mathbf{h}^{-\mathbf{1}}\end{array}$ \\
\hline $\mathrm{S} \# 001$ & 200 & $-/-$ \\
\hline $\mathrm{S} \# 002$ & 400 & $-/-$ \\
\hline $\mathrm{S} \# 003$ & 220 & $-/-$ \\
\hline $\mathrm{S} \# 004$ & 278 & 1.3 \\
\hline $\mathrm{S} \# 005$ & 265 & 1.3 \\
\hline $\mathrm{S} \# 006$ & 196 & 1.9 \\
\hline $\mathrm{S} \# 007$ & 200 & 1.5 \\
\hline
\end{tabular}

\section{5. $\mathrm{CO}_{2}$ concentration}

Fig. 6 depicts the course of the $\mathrm{CO} 2$ concentration in a room. The measurement started at $0 \mathrm{~h}$. The windows and the doors were closed for the next $0.6 \mathrm{~h}$. During that time, the concentration of $\mathrm{CO} 2$ increased due to the students' activity. A break at $0.6 \mathrm{~h}$ (children went outside and doors were opened) led to a reduction in $\mathrm{CO} 2$ level. At $0.65 \mathrm{~h}$, the class started again with an active part near the blackboard lasting until the end of the timeline. During the second part of the class, the $\mathrm{CO} 2$ concentration increased analogously to the course of the first class. Starting with a CO2-level of $1.200 \mathrm{ppm}$ at the beginning of the measurement the concentration established at $1.600 \mathrm{ppm}$ by the end of the first part of the class, while the outside concentration of $\mathrm{CO} 2$ was about $450 \mathrm{ppm}$. Ventilation by means of door opening during the break caused a reduction to an average $\mathrm{CO}$-concentration in the room of $1.350 \mathrm{ppm}$. Thus, approx. $1 / 4$ of the room volume was replaced by outside air. 

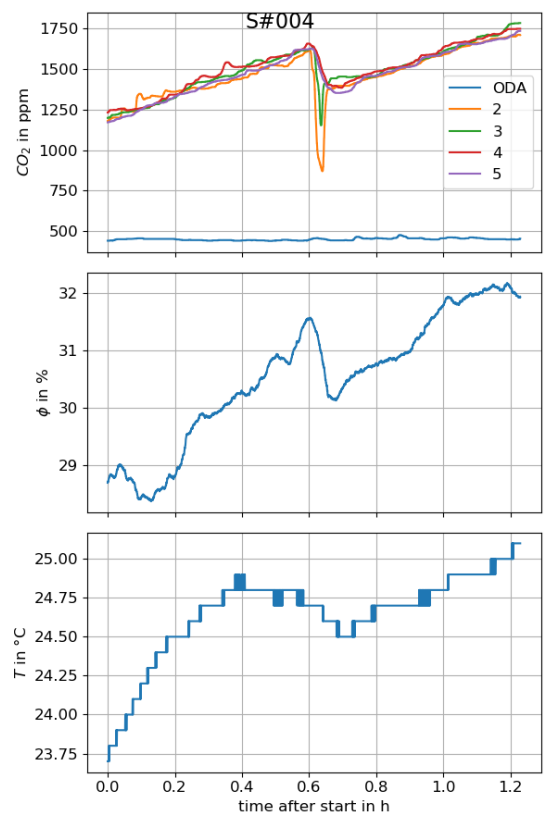

Fig. 6. Concentration of $\mathrm{CO}_{2}$, temperature and humidity.

\section{Analysis method}

The German Air Conditioning Association (Fachverband Gebäude-Klima e. V.) has defined requirements for ventilation and air purification to reduce the risk of infection via airborne particles in its Status Report 52 [6]. The basis of infection protection for these transmission paths (droplets and aerosols) are currently the rules regarding distance, hygiene and wearing a mask.

In the meantime, it has been proven that reducing the number of airborne germs through ventilation with outside air and/or air purification likewise will reduce the risk of infections significantly. Accordingly, ventilation was added to the rules above. The requirements for ventilation are defined in Status Report 52 [6]. The following evaluation of classrooms is based on this report.

The points below indicate the step-by-step procedure in the evaluation process. The determined data for the examined rooms are compiled in Table VI. The evaluation was carried out for classrooms with present students only.

1. Determination of the room volume and occupancy

2. Calculation of the required virus-free supply air volume flow in analogy with the requirements of EN 16798-1 Cat I, extended by an activity factor

3. Comparison of the available air volume flow with the required air volume flow. If this is sufficient, go to 5

4. Selection of the required measures (alternatively or combined):

a. Adjustment of occupancy

b. Increase of the fresh air flow rate

c. Additional air purification 
5. Documentation of the fulfilment of the requirements

Table 6. Evidence ventilation to reduce the risk of infection

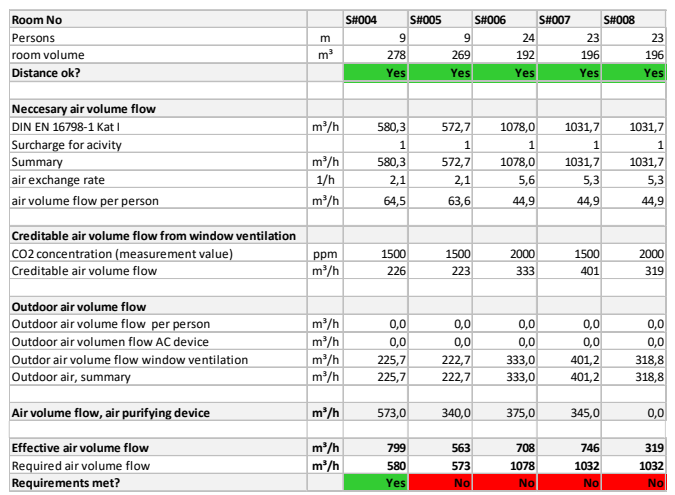

Table 6 proofs that only 1 out of 4 classrooms with air purifiers meet the ventilation requirements according to Status Report 52. The room S\#005 only just failed to meet the requirements. As a reminder, room $\mathrm{S} \# 008$ had no ventilation measures.

Both the air volume flow by means of window ventilation and the air volume flow by means of the air purifier are nearly similar in all classrooms. However, the two classrooms S\#006 and S\#007 were occupied by significantly more people than the classrooms S\#004 and S\#005. Consequently, these two classrooms are far from fulfilling the requirements.

Additionally, the air volume flow according to the manufacturer's data sheet of each cleaning device is listed in Table 4. This air flow volume is significantly higher than the air flow rate measured on site. It is suspected that the air flow rate was intentionally reduced when the units were installed in order to keep the noise emission low. In case of maximum air volume flow, the ventilation requirements for all classrooms except the room S\#008 without air purifier would be fulfilled.

\section{CONCLUSIONS}

Recirculating air cleaners reliably remove pathogens from the room air when the air volume flow is sufficiently high. Hence they are equivalent to ventilation systems or window ventilation. As a conclusion of the experiences made in this investigation, it can be stated that the air volume flow is always set clearly too low due to the noise emission.

All air purification units led to a reduction of particles in the room that fulfilled the expectations of the set air volume flow. Nonetheless, all units were found to be acceptable at the level operated in terms of noise and draught rate.

According to the results of the air volume flow calculation [6], only one out of eight rooms complies with the requirements in terms of ventilation criteria. The underlying cause is the reduced air flow due to the high noise emission at nominal volume flow rate. The room that fulfils the criterions of the said report, has low occupancy. Assuming that the units are operated at the maximum air volume flow, all classrooms examined meet the ventilation requirements. Accepting compromises in terms of noise and draught risk the installation of mobile air cleaning devices can be short-term solutions.

Irrespective of the effectiveness against pathogens or particles, the material loads, especially $\mathrm{CO} 2$, must be removed via ventilation systems or window ventilation. The use of 
air cleaning devices is only an additional measure. However, care must be taken to ensure that air purification is performed in the entire room and not only in partial areas.

With all technical measures, it must be noted that the use of air purifiers does not provide protection against direct infection. Rules for maintaining distance, observing hygiene and wearing masks still apply.

Regardless of the predominantly positive attitude of those involved (teachers, pupils, facility manager etc.) towards the measure, information about ventilation principles, equipment handling and maintenance is urgently required for the acceptance of infection risk-reducing measures.

\section{References}

[1] DIN EN ISO 7730 2006-05: Ergonomie der thermischen Umgebung - Analytische Bestimmung und Interpretation der thermischen Behaglichkeit durch Berechnung des PMV- und des PPD-Indexes und Kriterien der lokalen thermischen Behaglichkeit (ISO 7730:2005); Deutsche Fassung EN ISO 7730:2005 : Deutsches Institut für Normung, 2006

[2] DIN EN 12599:2013-01 Lüftung von Gebäuden - Prüf- und Messverfahren für die Übergabe raumlufttechnischer Anlagen; Deutsche Fassung EN 12599:2012 : Deutsches Institut für Normung, 2013

[3] CHEN, NANSHAN ; ZHOU, MIN ; DONG, XUAN ; QU, JIEMING ; GONG, FENGYUN ; HAN, YANG ; QIU, YANG ; WANG, JINGLI ; LIU, YING ; ET AL.: Epidemiological and clinical characteristics of 99 cases of 2019 novel coronavirus pneumonia in Wuhan, China: a descriptive study. In: The Lancet vol. 395 (2020), Nr. 10223, pp. 507-513

[4] VDI 2083 Blatt 3 2005-07: Reinraumtechnik - Messtechnik in der Reinraumluft : VDI, 2005

[5] DIN EN ISO 14644-3 2020-08: Reinräume und zugehörige Reinraumbereiche - Teil 3: Prüfverfahren (ISO 14644-3:2019, korrigierte Fassung 2020-06); Deutsche Fassung EN ISO 14644-3:201 : Deutsches Institut für Normung, 2020

[6] Anforderungen an Lüftung und Luftreinigung zur Reduktion des Infektionsrisikos über den Luftweg AHA + Lüftung : Fachverband Gebäude- Klima e.V., 2021 